\title{
Minireview
}

\section{Methanogenic Archaea and Methanotrophic Bacteria in a Subtropical Paddy Field and Their Interaction: Controlling Methane Emissions from Paddy Fields}

\author{
KATSUKI ADACHI ${ }^{1 *}$ \\ ${ }^{1}$ National Agricultural Research Center for Kyushu Okinawa Region, Department of Upland Research, \\ Miyakonojo, Miyazaki 885-0091, Japan
}

(Received September 28, 2001-Accepted October 26, 2001)

In flooded rice fields, methanogenic archaea produce $\mathrm{CH}_{4}$, while methanotrophic bacteria oxidize a part of the produced $\mathrm{CH}_{4}$. Thus, the latter bacteria are considered as suitable organisms for controlling $\mathrm{CH}_{4}$ emission from paddy fields. In this paper, the author demonstrates a case of organic matter application, enumeration and isolation of methanogenic archaea and methanotrophic bacteria in a subtropical paddy field. The rice rhizosphere is one of the typical areas where anaerobic and aerobic environments interface, methanogens produce $\mathrm{CH}_{4}$ and methanotrophs utilize it for energy. Although how they interact in the anaerobic and aerobic interfaces is an attractive research area, it has not yet been fully elucidated, because a two-member co-culture of methanogen and methanotroph is not well developed. Co-culture of a strictly anaerobic methanogenic archaeon and an obligately aerobic methanotrophic bacterium using sterilized paddy soil was carried out. The rice root system affects $\mathrm{CH}_{4}$ production and oxidation in the rice rhizosphere, and its influence varies with different rice cultivars. Rice cultivars with few unproductive tillers, a small root system, high root oxidative activity, and high harvest index are ideal for mitigating $\mathrm{CH}_{4}$ emission in paddy fields.

Key words: methane emission, methanogenic archaeon, methanotrophic bacterium, rice cultivar, subtropical paddy field

Methane is one of the significant greenhouse gases related to global warming, and its concentration in the global atmosphere is increasing at a rate of approximately $1 \%$ per year $^{11,35)}$. In lowland rice cultivation, rice plants grow under flooded conditions and $\mathrm{CH}_{4}$ is emitted from the fields. Controlling $\mathrm{CH}_{4}$ emission from the paddy fields contributes to the mitigation of global warming. Figure $1^{57}$ shows a sketch of a flooded rice field in relation to $\mathrm{CH}_{4}$ production, oxidation, and emission, along with $\mathrm{CH}_{4}$ diffusion, ebullition, and leaching from the paddy soil. Rice plants play the key role in $\mathrm{CH}_{4}$ emission from paddy fields: (1) they supply root exudate and detritus which are substrates for $\mathrm{CH}_{4}$ production $^{56)}$; (2) the rice aerenchyma system is a major pathway of $\mathrm{CH}_{4}$ from paddy soil to atmosphere ${ }^{13,42,46)}$; (3)

* Corresponding author; E-mail: kadachi@affrc.go.jp, Tel: +81986-22-1506, Fax: +81-986-23-1168 the aerenchyma system is also a pathway of $\mathrm{O}_{2}$ supply to the rice rhizosphere by downward transportation, thus rice plants support $\mathrm{CH}_{4}$ oxidation in the rhizosphere; and (4) the rice rhizosphere itself is an important niche for methanotrophic bacteria which oxidize $\mathrm{CH}_{4}$ to $\mathrm{CO}_{2}{ }^{56,63)}$.

Methanogenic archaea (methanogens) are strictly anaerobic microbes belonging to the Archaea domain, and play an important role in anoxic environments by performing the last step of the anaerobic decomposition of organic matter: mineralization into $\mathrm{CH}_{4}$ and $\mathrm{CO}_{2}{ }^{27)}$. Information on the genera and species of methanogenic archaea occurring in flooded paddy soils is gradually accumulating, but it is still limited. On the other hand, methanotrophic bacteria are obligately aerobic respiratory bacteria that can utilize $\mathrm{CH}_{4}$ as their sole carbon and energy source for growth, so they considered important regulators of atmospheric $\mathrm{CH}_{4}$ fluxes in nature ${ }^{15)}$. There is considerable interest in methanotrophs 


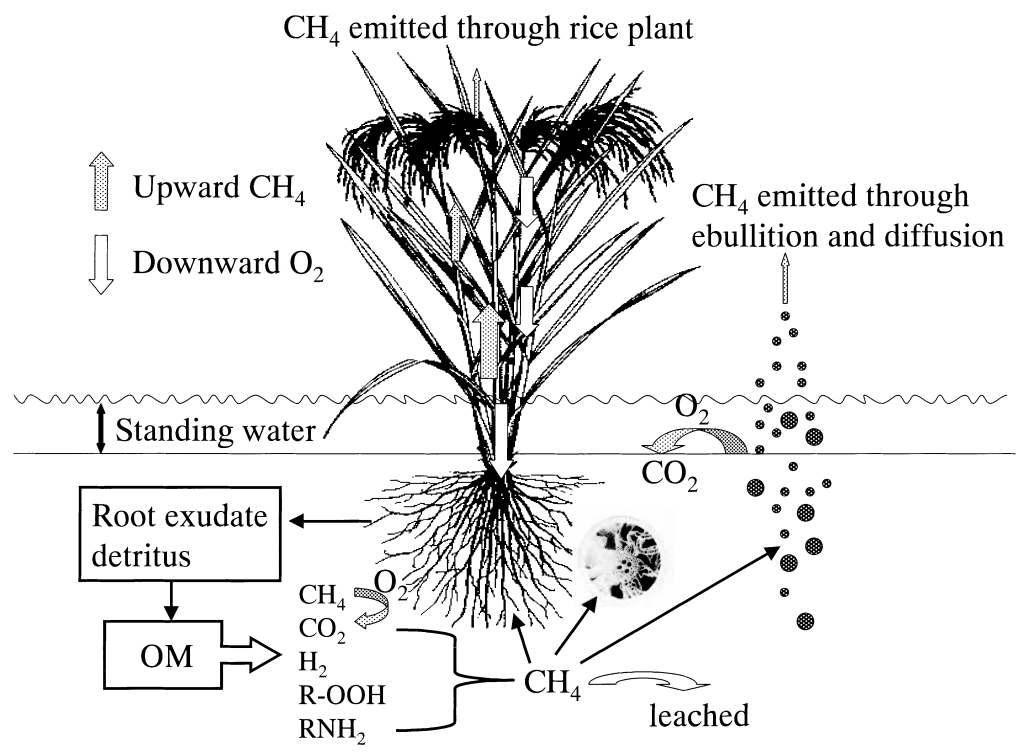

Fig. 1. Methane in a flooded rice field. OM, organic matter.

with respect to $\mathrm{CH}_{4}$ production and oxidation in paddy fields. Methanotrophic bacteria have been isolated from a variety of environments, however there is relatively little information on methanotrophic species in paddy fields.

Methanogenic archaea and methanotrophic bacteria are thought to inhabit the interfaces between anaerobic and aerobic environments, where methanogens produce $\mathrm{CH}_{4}$ and provide it to the methanotrophs which utilize it for energy. Kaku et al. ${ }^{28,29)}$ detected the population density of methanogens and methanogenic activity on rice roots. The rice rhizosphere in flooded paddy fields is one of the typical areas with interfacing anaerobic and aerobic environments. Gerritse and Gottschal ${ }^{22}$ showed two-member mixed cultures of a methanogenic archaeon and aerobic bacterium in $\mathrm{O}_{2}$-limited conditions in which the growth of Methanobacterium formicicum was dramatically inhibited in the co-culture with Methylocystis species. Shen et al. ${ }^{47)}$ reported methanotroph and methanogen coupling in granular biofilm under $\mathrm{O}_{2}$-limited conditions, however the coupling system included other aerobic and anaerobic bacteria. Hence a twomember co-culture of methanogen and methanotroph is not yet well developed, though they are thought to exist in anaerobic and aerobic interfaces in natural environments.

The ecology of either methanogenic archaea or methanotrophic bacteria in paddy fields is not fully elucidated, and the study of the relationship between them is even more limited. Understanding their relationship in relation to the mechanism of $\mathrm{CH}_{4}$ production, oxidation, and emission in paddy fields is essential for the control of $\mathrm{CH}_{4}$ emission from paddy fields.

\section{Effect of organic matter application on $\mathrm{CH}_{4}$ emission in a subtropical paddy field}

Application of organic matter enhanced $\mathrm{CH}_{4}$ emission in paddy fields ${ }^{38,39,45,65)}$. The author refers to the subtropical field experiment with rice straw and cellulose application at 4 and 10 t per ha ${ }^{2,20,43)}$, as an example of organic matter application in a subtropical paddy field. Five treatments [i.e., control (T1), application of rice straw at $4 \mathrm{tha}^{-1}$ (T2), rice straw at $10 \mathrm{tha}^{-1}$ (T3), cellulose at $4 \mathrm{t} \mathrm{ha}^{-1}$ (T4), cellulose at $10 \mathrm{t} \mathrm{ha}^{-1}$ (T5)] were set up using the rice cultivar Chiyonishiki ${ }^{2,20,43)}$. In this field experiment, the incubation period after incorporation of straw and cellulose until transplanting was set at more than 3 months under flooded conditions. Application of straw and cellulose at $10 \mathrm{t} \mathrm{ha}^{-1}$ to the paddy field increased $\mathrm{CH}_{4}$ emission 10- and 21-fold over the values of the control, respectively, as estimated by seasonal emissions (Fig. 2) ${ }^{43}$.

\section{Methanogenic archaea and methanotrophic bacteria in the subtropical paddy field}

Populations of methanogenic archaea in the subtropical paddy field

When an agar medium containing $30 \mathrm{mM}$ of formate and acetate, and $60 \mathrm{mM}$ of methanol with a top gas-phase of $\mathrm{H}_{2}$ $\mathrm{CO}_{2}$ (4:1) as growth substrates was used for enumeration by the roll tube method (counted as blue-autofluorescent colonies $)^{3)}$, methanogenic populations in the $10 \mathrm{t} \mathrm{ha}^{-1}$ straw plot 


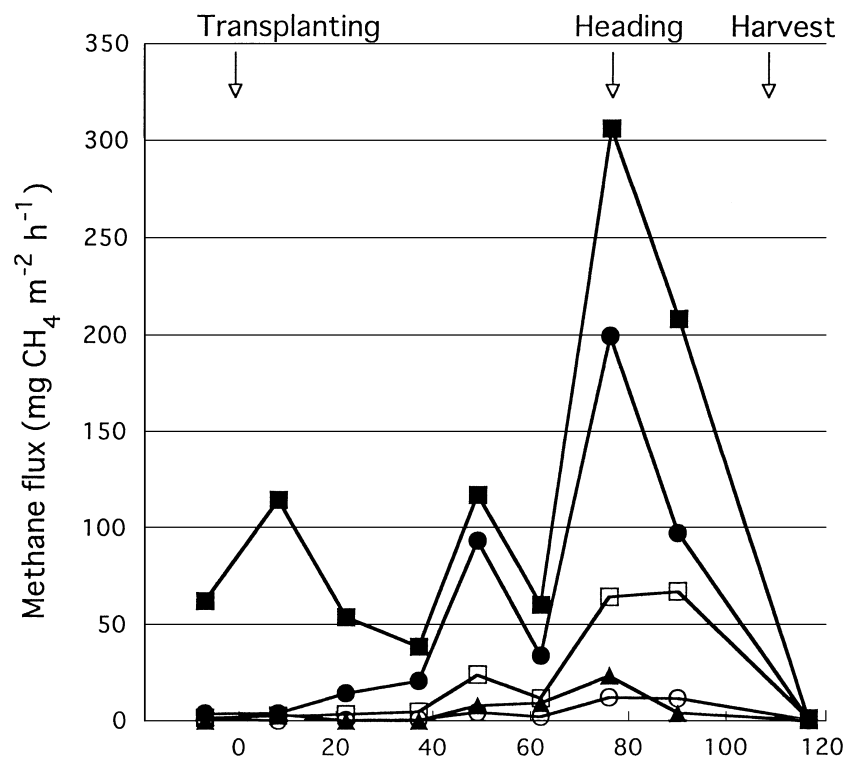

Days after transplanting

Fig. 2. Methane emission rates in treatment plots with applications of rice straw or cellulose at 4 and $10 \mathrm{t} \mathrm{ha}^{-1}$. $\mathbf{\Delta}$, control plot (T1); $\bigcirc$, application of rice straw at $4 \mathrm{t} \mathrm{ha}^{-1}$ (T2); 0 , application of rice straw at $10 \mathrm{tha}^{-1}$ (T3); $\square$, application of cellulose at $4 \mathrm{tha}^{-1}$ (T4); $\mathbf{\square}$, application of cellulose at $10 \mathrm{t} \mathrm{ha}^{-1}(\mathrm{~T} 5)$.

(T3) and the $10 \mathrm{t} \mathrm{ha}^{-1}$ cellulose plot (T5) in the subtropical paddy field were about 10-fold higher than in the control (T1) after transplanting up to harvest.

Asakawa and Hayano ${ }^{8)}$ elucidated that the level of methanogenic population in Japanese temperate paddy fields enumerated by the most probable number (MPN) method using three types of media containing $\mathrm{H}_{2}-\mathrm{CO}_{2}$, methanol, and acetate remained almost constant for two years irrespective of moisture regime (flooded or nonflooded), crop (rice or wheat), and wheat straw or fertilizer treatment. Asakawa et $\left.a l .{ }^{6}\right)$ also reported that long-term (over 30 years) application of rice straw compost at $20 \mathrm{t} \mathrm{ha}^{-1}$, approximate moisture $75 \%$, significantly increased methanogenic populations, but application of rice straw at $10 \mathrm{t} \mathrm{ha}^{-1}$ with an approximate moisture of $15 \%$ did not affect methanogenic communities. Comparing these results and the results in the subtropical paddy field ${ }^{3)}$ as to the effect of organic matter application on methanogenic populations, the $10 \mathrm{t} \mathrm{ha}^{-1}$ straw application caused enhancement of the population in the subtropical paddy field ${ }^{3)}$, but not in the other report ${ }^{6}$. . Possible reasons include not only climate, soil, and methodological differences, but also the more than 3-month-incubation period under flooded conditions from straw incorporation until rice transplanting in the subtropical paddy field experiment which might have induced enhancement of the methanogenic population, because anaerobic fermentation of rice straw was begun during this incubation period.

Comparing enumeration methods for methanogens, Asakawa's MPN method ${ }^{7)}$ using three types of media $\left(\mathrm{H}_{2}-\right.$ $\mathrm{CO}_{2}$, methanol, and acetate, as substrates) is recommended over the MPN method and roll tube method using the medium combined with substrates $\left(\mathrm{H}_{2}-\mathrm{CO}_{2}+\right.$ formate+methanol+acetate $)^{3)}$. The enumerated populations were higher by the MPN method than by the roll tube method in the report of Adachi et al. ${ }^{3)}$, and the use of 3 different media for methanogenic enumeration gave more accurate information than when the combined medium was used. In addition, distinguishing methanogenic colonies from non-methanogenic colonies under fluorescent microscope in the roll tube method was an essential but time-consuming step, because only several $\%$ up to $15 \%$ were methanogenic colonies among the total colonies formed in the roll tube cultures ${ }^{3}$. On the other hand, the roll tube method may give us unique information on the methanogenic community structure, because we can isolate individual methanogenic colonies ${ }^{1}$.

\section{Population of methanotrophic bacteria in the subtropical paddy field}

Levels of methanotrophic population in soil and rice rhizosphere with and without rice straw application (T1, T2, and T3) in the subtropical paddy field were enumerated by the MPN method (Fig. 3) ${ }^{20)}$ using the nitrate-mineral-salts medium developed by Whittenbury et al. ${ }^{64)}$ Soil samples were taken from the surface plow layer ( 0 to $5 \mathrm{~cm}$ depth) for population analysis in soil, while rice roots and rhizospheric soil near the roots were cut with scissors, ground gently, and mixed well for rhizospheric population analysis. Fluctuation of methanotrophic population in soil showed that (1) the straw application (T2 and T3) led to an increase in the population in soil compared to the control (T1) at the middle stages of rice growth (tillering to maximum-tillering stages), (2) the population declined to $3 \times 10^{3} \mathrm{~g}^{-1}$ dry soil, reaching the same level as in $\mathrm{T} 1$ after heading (81 days after transplanting (DAT)), and (3) the population increased to above $10^{4} \mathrm{~g}^{-1}$ soil in $\mathrm{T} 1, \mathrm{~T} 2$, and T3 after harvest (20 days after drainage). On the other hand, in the rhizosphere (1) the methanotrophic populations in $\mathrm{T} 1, \mathrm{~T} 2$, and $\mathrm{T} 3$ were about $10^{5} \mathrm{~g}^{-1}$ dry matter at 27 DAT, then declined to about $10^{4} \mathrm{~g}^{-1}$ matter at 59 DAT, increased again to about $10^{5} \mathrm{~g}^{-1}$ matter at 81 DAT around the heading stage, and (2) there were no significant differences among the three treatments, indicating that the application of rice straw had no effect on methanotrophic population in the rhizosphere. 


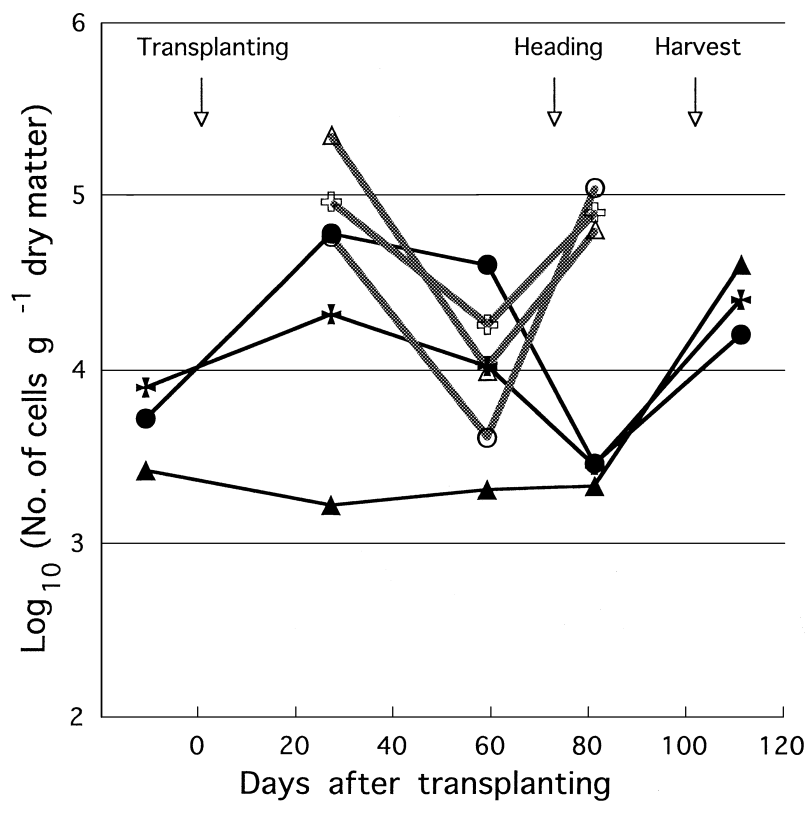

Fig. 3. Fluctuation of population levels of methanotrophic bacteria in soil and rice rhizosphere with and without rice straw application at 4 and $10 \mathrm{t} \mathrm{ha}^{-1}$. Solid lines represent population levels in soil with the symbols of $\boldsymbol{\Delta}$, control plot (T1), $\boldsymbol{\Psi}$, application of rice straw at $4 \mathrm{t} \mathrm{ha}^{-1}$ (T2), and $\mathbf{0}$, application of rice straw at $10 \mathrm{tha}^{-1}$ (T3). Gray and thick lines represent population levels in rice rhizosphere with the symbols of $\triangle$, control plot (T1), 引, rice straw at $4 \mathrm{tha}^{-1}$ (T2), and $\bigcirc$, rice straw at $10 \mathrm{t} \mathrm{ha}^{-1}(\mathrm{~T} 3)$.

Watanabe et al. ${ }^{63)}$ reported that methanotrophs, whose populations were $10^{6}-10^{5}$ per gram dry matter in rice roots and $10^{4}-10^{3}$ per gram dry matter in basal portion of rice stems, inhabited two Japanese rice cultivars, indicating the possibility of $\mathrm{CH}_{4}$ oxidation in association with wetland rice plants.

Isolation of methanogenic archaea from the subtropical paddy field

The genera and species of methanogenic archaea occurring in flooded paddy soils are as follows. Methanobacterium spp. ${ }^{14,21,23,27,34,44)}$ and Methanobrevibacter arboriphili$c u s^{9)}$ were isolated as hydrogenotrophic and/or formatotrophic methanogens, while Methanosarcina spp. ${ }^{10,21,23,27,34,44)}$ were isolated as acetate-utilizing ones. Recently, Methanoculleus chikugoensis sp. nov. was isolated and identified as a hydrogenotrophic, formatotrophic, and 2-propanol/ $\mathrm{CO}_{2}$-utilizing methanogen ${ }^{19)}$. Großkopf et al. ${ }^{23)}$ indicated Methanosaeta spp. and Methanobacterium spp. to be the dominant methanogenic groups in anoxic rice soil from the cultivation experiment and the experiment with direct 16S rRNA gene sequence retrieval.
Adachi $^{1)}$ isolated 36 hydrogenotrophic methanogenic strains from the subtropical paddy field in Ishigaki Island. Some of the isolates belonged to the genus Methanobacteri$u m$, while some showed irregularly crooked long rods, and seemed to represent a new species within the genus Methanobacterium or probably Methanobrevibacter by partial sequencing analysis of $16 \mathrm{~S}$ rRNA. Adachi ${ }^{1)}$ indicated that acetate-utilizing or methanol-utilizing methanogens in the subtropical paddy field were not obtained. Further experiments are required for elucidation of genera and species of methanogenic community structure in the subtropical paddy field.

Isolation of methanotrophic bacteria from the subtropical paddy field

Although methanotrophic bacteria are thought to be ubiquitous in most terrestrial habitats, there are relatively few reports on the methanotrophic species isolated from paddy fields ${ }^{24-26,33,49-51,53)}$. Recently, Van Bodegom et al. ${ }^{55)}$ isolated a Methylocystis sp. from the soil slurry which was prepared from air-dried paddy soil from the Philippines.

Dianou et al. ${ }^{16,18)}$ isolated 21 methanotrophic strains from the subtropical paddy field in Ishigaki Island (18 isolates from rice rhizosphere, and 3 from paddy soil). These isolates were straight or slightly curved, short or long rods, and all were able to fix nitrogen. Among the 21 isolates, two strains, R16 and R18, from the rice rhizosphere were selected for further experiments ${ }^{16)}$. On the basis of morphological and physiological properties, as well as $16 \mathrm{~S}$ rRNA gene sequence analysis, the two strains were identified as genus Methylosinus. According to the revised taxonomy proposed by Bowman et al. ${ }^{12)}$, group I methanotrophs consists of $\mathrm{Me}$ thylomonas, Methylobacter, and Methylococcus, whereas group II consists of Methylosinus and Methylocystis. Takeda et $a l .{ }^{52)}$ reported that group II methanotrophs seem to be dominant in rice soils under low- $\mathrm{O}_{2}$ and high- $\mathrm{CH}_{4}$ conditions. Dianou and Adachi ${ }^{16)}$ also assumed that the majority of methanotrophic bacteria in flooded paddy fields may belong to group II. Tsien et al. ${ }^{54)}$ examined methanotrophic bacteria with whole cell hybridization as a means of distinguishing group I and group II by utilizing group-specific probes of $10-\gamma$ or $9-\alpha$, respectively.

\section{Co-culture of a methanogenic archaeon and a metha- notrophic bacterium for establishment of a model eco- system of $\mathrm{CH}_{4}$ production, oxidation, and emission}

Development of a model ecosystem of $\mathrm{CH}_{4}$ production and oxidation is essential for understanding the mechanism of $\mathrm{CH}_{4}$ emission from wetland paddy fields ${ }^{18,41)}$. Further- 
more, the development of such a model ecosystem should prove a helpful device for all techniques employed in biological environmental control of $\mathrm{CH}_{4}$ emission from paddy fields as one of the major anthropogenic sources of $\mathrm{CH}_{4}$ emission to the atmosphere ${ }^{35,61)}$.

Dianou and Adachi ${ }^{17)}$ reported a soil-mediated co-culture of a methanogen and a methanotroph using sterilized paddy soil. The $\mathrm{CH}_{4}$ emission, i.e., the balance of $\left[\left(\mathrm{CH}_{4}\right.\right.$ production $)-\left(\mathrm{CH}_{4}\right.$ oxidation $)-\left(\mathrm{CH}_{4}\right.$ dissolved in soil phase $\left.)\right]$, into the top gas phase in the experimental system for soil-mediated co-culture (Fig. 4) ${ }^{17)}$ suggests a symbiotic relation in this co-culture system, because the methanogen provided $\mathrm{CH}_{4}$ to the methanotroph, while the inoculation of methanotroph was necessary for subsequent production of $\mathrm{CH}_{4}$ by

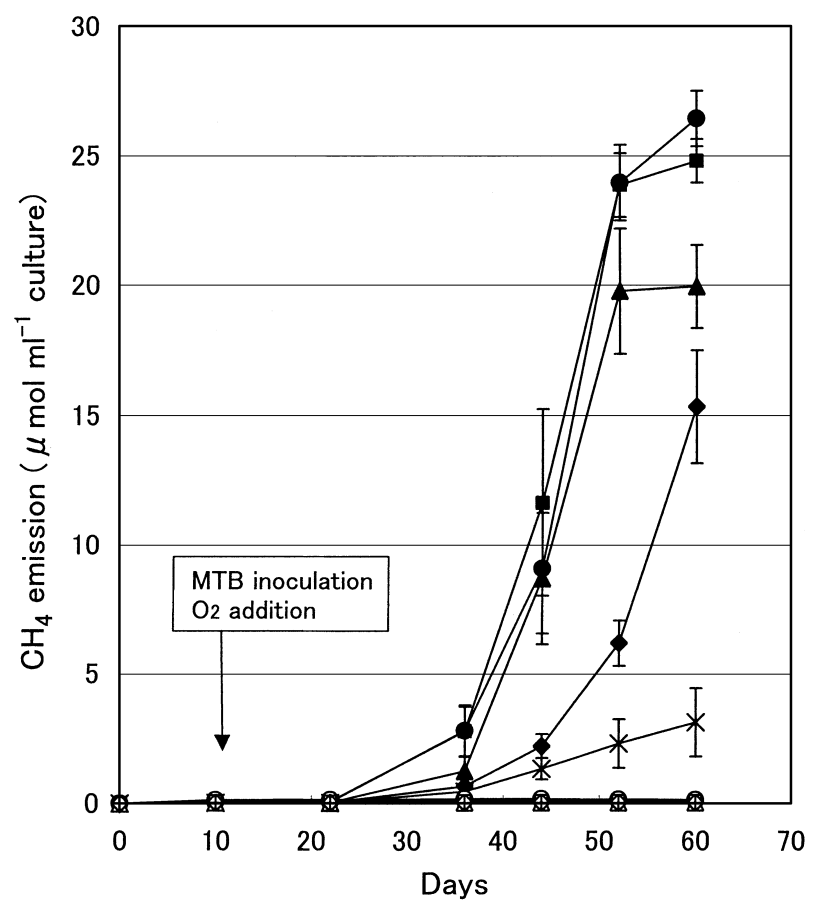

Fig. 4. Effect of methanotroph inoculation on $\mathrm{CH}_{4}$ emission into headspaces in soil-mediated co-culture under different concentrations of $\mathrm{O}_{2}$ in the presence of methanogen (Methanobrevibacter arboriphilicus strain SA). Vertical bars present standard deviations of four replications. MTB, methanotrophic bacterium, $M e$ thylosinus sp. strain R16. $\mathrm{O}$, MTB inoculated at $0 \% \mathrm{O}_{2} ; \mathbf{\square}$, MTB inoculated at $2 \% \mathrm{O}_{2} ; \boldsymbol{\Delta}$, MTB inoculated at $5 \% \mathrm{O}_{2} ; \boldsymbol{\wedge}$, MTB inoculated at $10 \% \mathrm{O}_{2} ; \times$, MTB inoculated at $16 \% \mathrm{O}_{2} ; \bigcirc$, without MTB inoculation at $0 \% \mathrm{O}_{2} ; \square$, without MTB inoculation at $2 \%$ $\mathrm{O}_{2} ; \triangle$, without MTB inoculation at $5 \% \mathrm{O}_{2} ; \diamond$, without MTB inoculation at $10 \% \mathrm{O}_{2} ;+$, without MTB inoculation at $16 \% \mathrm{O}_{2}$. In the 5 treatments with the methanogen without MTB inoculation under 5 levels of $\mathrm{O}_{2}$ addition, $\mathrm{CH}_{4}$ concentrations in the headspaces were very low (within the range of 0.03 to $0.17 \mu \mathrm{mol} \mathrm{ml}^{-1}$ culture solution $\pm<0.02$ ) throughout the incubation period. the methanogen. The activity of the methanotroph probably created anaerobic conditions in the soil suitable for methanogenic activity, protecting the methanogen from $\mathrm{O}_{2}$-toxicity. This short report ${ }^{17)}$ presents a preliminary stage in the development of a co-culture of a methanogen and a methanotroph.

As Espiritu et al. $^{20)}$ mentioned, the population fluctuations of methanotrophs in paddy soil and rice rhizosphere are likely to be closely affected by the supply of $\mathrm{O}_{2}$, namely reduced or oxidative conditions, at each stage of rice cultivation. The studies of Amaral and Knowles ${ }^{5}$, and Amaral et al. ${ }^{4)}$ suggested a possible new model ecosystem based on the two-member co-culture of a methanogen and methanotroph for the study of the production, oxidation, and emission of $\mathrm{CH}_{4}$ in paddy soil. The development of the co-culture design without soil-mediation would be attractive research topic, even though it would not be easy. Further experiments are required for the establishment of a new model ecosystem of two-member co-culture of a methanogen and a methanotroph for $\mathrm{CH}_{4}$ production, oxidation, and emission in paddy soil.

\section{Effect of rice cultivars on $\mathrm{CH}_{4}$ emission from the paddy field concerning the ecology of methano- trophic bacteria in rice rhizosphere}

Oyediran et al. ${ }^{43)}$ and Espiritu et al. ${ }^{20)}$ found in subtropical paddy field experiments that (1) straw application at $10 \mathrm{t}$ $\mathrm{ha}^{-1}$ to the subtropical paddy field increased seasonal $\mathrm{CH}_{4}$ emission 10-fold over the values of the control (Fig. 2), and (2) straw application at $10 \mathrm{t} \mathrm{ha}^{-1}$ had no effect on the methanotrophic population in the rice rhizosphere (Fig. 3). However, because the rice aerenchyma system is the major pathway of $\mathrm{CH}_{4}$ emission from paddy soils to atmosphere ${ }^{13,42,46)}$, most of the $\mathrm{CH}_{4}$ is emitted through the rice plants themselves. In the plot of straw application at $10 \mathrm{tha}^{-1}$ (T3), the amount of $\mathrm{CH}_{4}$ transported through rice rhizosphere and roots should also be much higher than that in the control plot (T1). In considering possible reasons why methanotrophic populations in the rice rhizosphere were the same level between $\mathrm{T} 1$ and $\mathrm{T} 3$, the following two hypotheses emerged. Hypothesis 1: even though the energy source $\left(\mathrm{CH}_{4}\right)$ was sufficient, $\mathrm{O}_{2}$ supply to rice rhizosphere by downward transportation through aerenchyma systems regulated the methanotrophic multiplication in the rice rhizosphere. Hypothesis 2: the rice root structure itself regulated the 'niche' spaces for the methanotrophic bacteria in rice root area (Fig. 5). Based on these ideas, Wang and Adachi ${ }^{56)}$ studied the effect of rice cultivars on the $\mathrm{CH}_{4}$-oxidizing activity and the population of methanotrophic bacteria in rice 


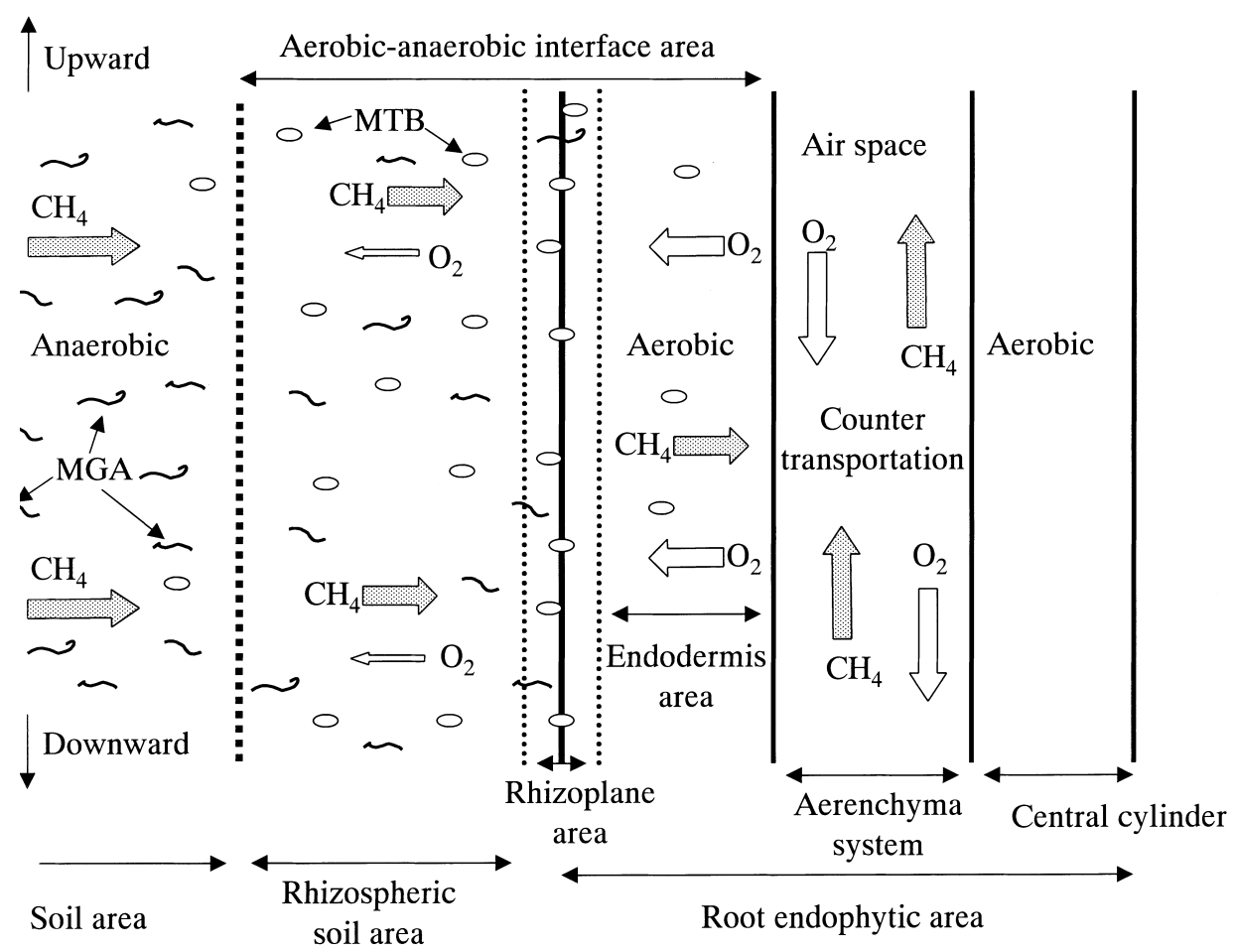

Fig. 5. Schema of rice root detailing the aerobic-anaerobic interface, $\mathrm{O}_{2}-\mathrm{CH}_{4}$-counter transportation, and niches of methanogenic archaea and methanotrophic bacteria. MGA, methanogenic archaea; MTB, methanotrophic bacteria.

rhizosphere in relation to $\mathrm{CH}_{4}$ emission. Different cultivars may well supply different $\mathrm{O}_{2}$ transport potentials, which support $\mathrm{CH}_{4}$ oxidation in rice rhizosphere, and also may supply different conditions of 'niche' spaces in rice roots for methanotrophic bacteria. Watanabe et al. ${ }^{63)}$ reported methanotrophic populations associated with rice plants of two different rice cultivars, and suggested that methanotrophs were present inside the tissues of roots and lower stems.

As measures to control $\mathrm{CH}_{4}$ emission from paddy fields, mitigation options have been reported ${ }^{32,36,37,40,60,61,66)}$, including (1) organic matter management, (2) water management, (3) selection of rice cultivar, and (4) chemical fertilizer. In this minireview, we focus on the effect of rice cultivars on $\mathrm{CH}_{4}$ emission from the paddy field as a possible measure for controlling $\mathrm{CH}_{4}$ emission.

A well-developed aerenchyma system supports both $\mathrm{O}_{2}$ transportation (downward transportation) and $\mathrm{CH}_{4}$ transportation from the rice rhizosphere to the atmosphere $\left(\mathrm{CH}_{4}\right.$ and $\mathrm{O}_{2}$ exchange ${ }^{30)}$, counter transportation, in Fig. 5). Hence, in relation to the effect of rice cultivars on $\mathrm{CH}_{4}$ emission from the paddy field, a key question is whether higher oxidative activity in roots of certain rice cultivars would cause lower $\mathrm{CH}_{4}$ emission through the rice plants.

Previous studies have been conducted to show the effect of different cultivars on $\mathrm{CH}_{4}$ emission ${ }^{31,40,48,56-59,62,63,67)}$. Neue et al. ${ }^{40)}$ reported that (1) cultivar choice markedly influenced both regional and global $\mathrm{CH}_{4}$ emissions from rice fields, but that (2) rice cultivar selection for lower $\mathrm{CH}_{4}$ emissions based solely on gas transport capabilities of the cultivars would not be a very useful screening procedure; the quantity and quality of root exudates together with the in situ $\mathrm{CH}_{4}$ oxidation capabilities should also be considered. Neue ${ }^{37)}$ also mentioned that the large variability of characteristics of rice plants which affect $\mathrm{CH}_{4}$ emission provides an opportunity to breed cultivars with high yield but low $\mathrm{CH}_{4}$ emission potentials. Wang et al. ${ }^{58)}$ found high correlations between $\mathrm{CH}_{4}$ emission rates and dry root weight, and between dry root weight and total carbon released from roots (root exudates). They also reported that traditional rice cultivar Dular had the highest $\mathrm{CH}_{4}$ emission rate, followed by modern cultivar IR72, while newly developed high yield plant type (new plant type) IR65598 had the lowest $\mathrm{CH}_{4}$ emission rate among the three cultivars.

Wang and Adachi ${ }^{56)}$ investigated the effect of cultivar difference on $\mathrm{CH}_{4}$ emission and methanotrophic population in rice roots by planting three rice cultivars; IR72 (modern cultivar, Indica rice), IR65598 (new plant type, Tropical japonica rice), and Chiyonishiki (Japonica rice), in subtropical 
Table 1. Shoot dry weight, root dry weight, $\mathrm{CH}_{4}$ emission rate, root air-space (\%), and methanotrophic population level of the 3 rice cultivars at 3 different growth stages (pot experiment, 1 plant pot $^{-1}$ ). Values are means of three replications \pm SD (standard deviation). WAT, weeks after transplanting.

\begin{tabular}{|c|c|c|c|c|c|c|c|}
\hline \multirow[b]{2}{*}{ Growth stage } & \multirow[b]{2}{*}{ Cultivar } & \multirow{2}{*}{$\begin{array}{l}\text { Shoot dry } \\
\text { weight } \\
\left(\text { g plant }^{-1}\right)\end{array}$} & \multirow{2}{*}{$\begin{array}{l}\text { Root dry } \\
\text { weight } \\
\left(\text { g plant }^{-1}\right)\end{array}$} & \multirow{2}{*}{$\begin{array}{c}\mathrm{CH}_{4} \text { emission } \\
\text { rate } \\
\left(\mathrm{mg}^{-1} \operatorname{pot}^{-1} \mathrm{~h}^{-1}\right)\end{array}$} & \multirow{2}{*}{$\begin{array}{l}\text { Root } \\
\text { air-space } \\
(\%)\end{array}$} & \multicolumn{2}{|c|}{ Methanotrophic population level } \\
\hline & & & & & & $\begin{array}{l}\text { population in roots } \\
\text { (No. } \mathrm{g}^{-1} \text { dry roots) }\end{array}$ & $\begin{array}{l}\text { population in soil } \\
\text { (No. } \mathrm{g}^{-1} \text { dry soil) }\end{array}$ \\
\hline Tillering & IR72 & $9.33 \pm 1.16$ & $2.70 \pm 0.54$ & $0.380 \pm 0.107$ & $27.8 \pm 4.8$ & $5.8 \times 10^{5}$ & $3.1 \times 10^{5}$ \\
\hline \multirow[t]{2}{*}{ (4 WAT) } & IR65598 & $7.60 \pm 1.08$ & $2.32 \pm 0.40$ & $0.304 \pm 0.157$ & $22.3 \pm 5.1$ & $3.4 \times 10^{5}$ & $2.0 \times 10^{5}$ \\
\hline & Chiyonishiki & $6.59 \pm 0.50$ & $1.54 \pm 0.07$ & $0.239 \pm 0.015$ & $24.7 \pm 2.6$ & $4.5 \times 10^{5}$ & $3.2 \times 10^{5}$ \\
\hline Flowering & IR72 & $20.82 \pm 2.54$ & $4.15 \pm 0.96$ & $1.648 \pm 0.186$ & $21.7 \pm 5.1$ & - & $4.6 \times 10^{6}$ \\
\hline \multirow[t]{2}{*}{ (11 WAT) } & IR65598 & $15.65 \pm 2.28$ & $2.83 \pm 0.54$ & $0.979 \pm 0.279$ & $26.7 \pm 4.8$ & - & $1.3 \times 10^{6}$ \\
\hline & Chiyonishiki & $17.24 \pm 2.54$ & $1.79 \pm 0.24$ & $1.826 \pm 0.209$ & $20.3 \pm 2.5$ & - & $3.5 \times 10^{6}$ \\
\hline Ripening & IR72 & $29.45 \pm 2.72$ & $3.63 \pm 0.54$ & $2.252 \pm 0.461$ & $16.9 \pm 2.8$ & $4.5 \times 10^{6}$ & $2.8 \times 10^{5}$ \\
\hline \multirow[t]{2}{*}{ (14 WAT) } & IR65598 & $20.50 \pm 4.42$ & $3.06 \pm 0.84$ & $0.664 \pm 0.252$ & $15.0 \pm 3.3$ & $6.5 \times 10^{7}$ & $3.6 \times 10^{4}$ \\
\hline & Chiyonishiki & $15.82 \pm 3.20$ & $2.23 \pm 0.43$ & $1.775 \pm 0.517$ & $12.0 \pm 3.9$ & $4.2 \times 10^{6}$ & $3.7 \times 10^{4}$ \\
\hline
\end{tabular}

Data: Wang and Adachi ${ }^{56}$

paddy soil (pot experiment, 1 plant pot $^{-1}$ ). Measurements of dry shoot weight, dry root weight, $\mathrm{CH}_{4}$ emission rate, root air-space (\%), and methanotrophic population level of the cultivars at three different growth stages (Table $1^{56}$ ) showed that differences in $\mathrm{CH}_{4}$ emission rates among the three rice cultivars became evident at the later plant growth stages of flowering and ripening. Cultivar IR65598 had the lowest $\mathrm{CH}_{4}$ emission rate among the three, and the population level of methanotrophic bacteria in roots of IR65598 at the ripening stage was significantly higher than that in IR72 or Chiyonishiki. The author focusses on the relevant connection between low $\mathrm{CH}_{4}$ emission rate and high methanotrophic population in roots of cultivar IR65598. Root air-space did not differ significantly among the cultivars, but the author observed that the root of IR65598 was thicker (in diameter) than those of the other cultivars. It is suggested that cultivar IR65598 may supply more 'niche' in roots for methanotrophic bacteria. The agronomic characteristics of cultivar IR65598 included fewer tillers, larger panicles, thicker roots (in diameter) in a relatively small root system, and a taller plant compared with IR72 and Chiyonishiki in the pot experiment. Rice cultivars with few unproductive tillers, a small root system, high root oxidative activity, and high harvest index are ideal for mitigating $\mathrm{CH}_{4}$ emission in paddy fields ${ }^{56)}$.

\section{Conclusion}

Methanogenic archaea (Methanobacterium spp.) and methanotrophic bacteria (Methylosinus spp.) were isolated, and fluctuations of their populations were examined in a subtropical paddy field.

Methanotrophic bacteria in paddy fields are beneficial in two ways. (1) $\mathrm{CH}_{4}$ oxidation to $\mathrm{CO}_{2}$ in paddy fields is an efficient means to mitigate global warming (radiative absorption potential of one molecule of $\mathrm{CH}_{4}$ is 32 times higher than that of $\mathrm{CO}_{2}$ ), and (2) group II methanotrophs, which are capable of fixing $\mathrm{N}_{2}$ and formation of exospore or cyst as dormant bodies, seem to be dominant in rice soils under low- $\mathrm{O}_{2}$ and high- $\mathrm{CH}_{4}$ conditions ${ }^{16,18,52)}$. They may also potentially support $\mathrm{N}$ fertility in paddy fields.

Rice root systems affect $\mathrm{CH}_{4}$ production and oxidation in the rice rhizosphere, and their influence varies with different rice cultivars. Here we assume that, in seeking measures to control $\mathrm{CH}_{4}$ emission from paddy fields in relation to rice cultivars, the root oxidative activity or niche for methanotrophic bacteria in the root areas is important (Fig. 5).

The ecological study of the interaction between methanogenic archaea and methanotrophic bacteria in anaerobic and aerobic interfaces is an attractive research subject. The development of a two-member co-culture of a methanogen and a methanotroph is a logical first step. One such anaerobic and aerobic interface found in the natural environment is the rice rhizosphere (Fig. 5).

\section{Acknowledgements}

The author expresses his gratitude to Dr. G. Oyediran, Dr. W. Chaitep, Dr. B.M. Espiritu, Dr. D. Dianou, and Dr. B. Wang for their collaboration at the International Collaboration Research Section, Okinawa Subtropical Station, Ja- 
pan International Research Center for Agricultural Sciences (JIRCAS), from 1992 to 1998. The author is also indebted to Dr. N. Maeno, JIRCAS, and to Dr. T. Senboku, Dr. K. Nakamura, Dr. S. Yashima and Dr. T. Hayashi, Okinawa Subtropical Station, JIRCAS, for their support. Thanks are also due to Dr. I. Watanabe, professor emeritus of Mie University, for his helpful comments during the collaboration research at Okinawa Subtropical Station, JIRCAS, and to Dr. K. Minamisawa, Tohoku University, for critical reading of this manuscript.

\section{References}

1) Adachi, K. 1999. Isolation of hydrogenotrophic methanogenic archaea from a subtropical paddy field. FEMS Microbiol. Ecol. 30: 77-85.

2) Adachi, K., W. Chaitep and T. Senboku. 1997. Promotive and inhibitory effects of rice straw and cellulose application on rice plant growth in pot and field experiments. Soil Sci. Plant Nutr. 43: 369-386.

3) Adachi, K., G. Oyediran and T. Senboku. 1996. Effect of application of rice straw and cellulose on methane emission and biological nitrogen fixation in a subtropical paddy field. II. Enumeration of populations of methanogenic bacteria by most probable number method and roll tube method. Soil Sci. Plant Nutr. 42: 713723.

4) Amaral, J.A., C. Archambault, S.R. Richards and R. Knowles. 1995. Denitrification associated with groups I and II methanotrophs in a gradient enrichment system. FEMS Microbiol. Ecol. 18: 289-298.

5) Amaral, J.A. and R. Knowles. 1995. Growth of methanotrophs in methane and oxygen counter gradients. FEMS Microbiol. Lett. 126: 215-220.

6) Asakawa, S., M. Akagawa-Mastushita, Y. Koga and K. Hayano. 1998. Communities of methanogenic bacteria in paddy field soils with long-term application of organic matter. Soil Biol. Biochem. 30: 299-303.

7) Asakawa, S., Y. Koga and K. Hayano. 1996. Enumeration of methanogenic bacteria in paddy field soil by the most probable number (MPN) method. Soil Microorganisms 47: 31-36 (in Japanese).

8) Asakawa, S. and K. Hayano. 1995. Populations of methanogenic bacteria in paddy field soil under double cropping conditions (rice-wheat). Biol. Fertil. Soils 20: 113-117.

9) Asakawa, S., H. Morii, M. Akagawa-Matsushita, Y. Koga and K. Hayano. 1993. Characterization of Methanobrevibacter arboriphilicus SA isolated from a paddy field soil and DNA-DNA hybridization among $M$. arboriphilicus strains. Int. J. Syst. Bacteriol. 43: $683-686$

10) Asakawa, S., M. Akagawa-Matsushita, H. Morii, Y. Koga and K. Hayano. 1995. Characterization of Methanosarcina mazeii TMA isolated from a paddy field soil. Curr. Microbiol. 31: 34-38.

11) Bouwman, A.F. 1989. The role of soils and land use in the greenhouse effect. Neth. J. Agric. Sci. 37: 13-19.

12) Bowman, J.P., L.I. Sly, P.D. Nichols and A.C. Hayward. 1993. Revised taxonomy of the methanotrophs: Description of Methylobacter gen. nov., emendation of Methylococcus, validation of Methylosinus and Methylocystis species, and a proposal that the family Methylococcaceae includes only the group I methanotrophs. Int. J. Syst. Bacteriol. 43: 735-753.
13) Byrnes, B.H., E.R. Austin and B.K. Tays. 1995. Methane emissions from flooded rice soils and plants under controlled conditions. Soil Biol. Biochem. 27: 331-339.

14) Conrad, R., F. Bak, H.J. Seitz, B. Thebrath, H.P. Mayer and H. Schütz. 1989. Hydrogen turnover by psychrotrophic homoacetogenic and mesophilic methanogenic bacteria in anoxic paddy soil and lake sediment. FEMS Microbiol. Ecol. 62: 285-294.

15) Denier van der Gon, H.A.C. and H.U. Neue. 1996. Oxidation of methane in the rhizosphere of rice plants. Biol. Fertil. Soils 22: 359-366.

16) Dianou, D. and K. Adachi. 1999. Characterization of methanotrophic bacteria isolated from a subtropical paddy field. FEMS Microbiol. Lett. 173: 163-173.

17) Dianou, D. and K. Adachi. 2001. Co-culture of a methanogenic archaeon and a methanotrophic bacterium on sterilized soil in large test tubes: Design for soil-mediated co-culture. Microb. Environ. 16: 222-226.

18) Dianou, D., B.M. Espiritu, K. Adachi and T. Senboku. 1997. Isolation and some properties of methane-oxidizing bacteria from a subtropical paddy field. Soil Sci. Plant Nutr. 43: 735-740.

19) Dianou, D., T. Miyaki, S. Asakawa, H. Morii, K. Nagaoka, H. Oyaizu and S. Matsumoto. 2001. Methanoculleus chikugoensis sp. nov., a novel methanogenic archaeon isolated from a paddy field soil in Japan and DNA-DNA hybridization among Methanoculleus species. Int. J. Syst. Evol. Microbiol. 51: 1663-1669.

20) Espiritu, B.M., K. Adachi and T. Senboku. 1997. Effect of application of rice straw and cellulose on methane emission and biological nitrogen fixation in a subtropical paddy field. III. Populations of methane-oxidizing bacteria in soil and rice rhizosphere. Soil Sci. Plant Nutr. 43: 729-734.

21) Fetzer, S., F. Bak and R. Conrad. 1993. Sensitivity of methanogenic bacteria from paddy soil to oxygen and desiccation. FEMS Microbiol. Ecol. 12: 107-115.

22) Gerritse, J. and J.C. Gottschal. 1993. Two-membered mixed cultures of methanogenic and aerobic bacteria in $\mathrm{O}_{2}$-limited chemostats. J. Gen. Microbiol. 139: 1853-1860.

23) Großkopf, R., P.H. Janssen and W. Liesack. 1998. Diversity and structure of the methanogenic community in anoxic rice paddy soil microcosms as examined by cultivation and direct 16S rRNA gene sequence retrieval. Appl. Environ. Microbiol. 64: 960-969.

24) Hanson, R.S., A.I. Netrusov and K. Tsuji. 1992. The obligate methanotrophic bacteria Methylococcus, Methylomonas, and Methylosinus, p. 2350-2364. In H. Balows, H.G. Trüper, M. Dworkin, W. Harder and K.H. Schleifer (ed.), The procaryotes, 2nd edn., Springer-Verlag, New York.

25) Hanson, R.S. and E.V. Wattenberg. 1991. Ecology of methylotrophic bacteria, p. 325-348. In I. Goldberg and J.S. Rokem (ed.), Biology of methylotrophs, Butterworth-Heinemann, Boston, MA.

26) Holzapfel-Pschorn, A., R. Conrad and W. Seiler. 1985. Production, oxidation and emission of methane in rice paddies. FEMS Microbiol. Ecol. 31: 343-351.

27) Joulian, C., B. Ollivier, B.K.C. Patel and P.A. Roger. 1998. Phenotypic and phylogenetic characterization of dominant culturable methanogens isolated from ricefield soils. FEMS Microbiol. Ecol. 25: 135-145.

28) Kaku, N., A. Ueki, H. Fujii and K. Ueki. 1997. Analysis of methanogenic microbial ecosystem in paddy field soil: Distributions of various bacteria and methanogenic activity on rice roots and plant residue. Environ. Sci. 10: 51-62 (in Japanese with English summary).

29) Kaku, N., A. Ueki, H. Fujii and K. Ueki. 2000. Methanogenic activities on rice roots and plant residue and their contributions to methanogenesis in wetland rice field soil. Soil Biol. Biochem. 32: 
2001-2010.

30) Kludze, H.K., R.D. DeLaune and W.H. Patrick, Jr. 1993. Aerenchyma formation and methane and oxygen exchange in rice. Soil Sci. Soc. Am. J. 57: 386-391.

31) Lindau, C.W., P.K. Bollich and R.D. DeLaune. 1995. Effect of rice variety on methane emission from Louisiana rice. Agric. Ecosys. Environ. 54: 109-114.

32) Lu, W.F., W. Chen, B.W. Duan, W.M. Guo, Y. Lu and R.S. Lantin. 2000. Methane emissions and mitigation options in irrigated rice fields in southeast China. Nutr. Cycling Agroecosys. 58: 6573.

33) Mancinelli, R.L. 1995. The regulation of methane oxidation in soil. Annu. Rev. Microbiol. 49: 581-605.

34) Min, H., Y.H. Zhao, M.C. Chen and Y. Zhao. 1997. Methanogens in paddy rice soil. Nutr. Cycling Agroecosys. 49: 163-169.

35) Minami, K. and H.U. Neue. 1994. Rice paddies as a methane source. Clim. Change 27: 13-26.

36) Neue, H.U. 1993. Methane emission from rice fields: Wetland rice fields may make a major contribution to global warming. BioScience, 43: 466-474.

37) Neue, H.U. 1997. Fluxes of methane from rice fields and potential for mitigation. Soil Use and Management 13: 258-267.

38) Neue, H.U., R.S. Lantin, R. Wassmann, J.B. Aduna, M.C.R. Alberto and M.J.F. Andales. 1994. Methane emission from rice soils of the Philippines, p. 55-63. In K. Minami, A. Mosier and R. Sass (ed.), $\mathrm{CH}_{4}$ and $\mathrm{N}_{2} \mathrm{O}$ : Global emissions and controls from rice fields and other agricultural and industrial sources, Yokendo Publishers, Tokyo.

39) Neue, H.U. and R.L. Sass. 1994. Trace gas emissions from rice fields, p. 119-147. In R.G. Prinn (ed.), Global atmosphericbiospheric chemistry, Plenum Press, New York.

40) Neue, H.U., R. Wassmann, H.K. Kludze, B. Wang and R.S. Lantin. 1997. Factors and processes controlling methane emissions from rice fields. Nutr. Cycling Agroecosys. 49: 111-117.

41) Nouchi, I. 1995. What is the mechanism of methane release from rice paddies to the atmosphere? Kagaku to Seibutsu (Chem. Biol.) 33: 560-563 (in Japanese).

42) Nouchi, I., S. Mariko and K. Aoki. 1990. Mechanism of methane transport from the rhizosphere to the atmosphere through rice plants. Plant Physiol. 94: 59-66.

43) Oyediran, G., K. Adachi and T. Senboku. 1996. Effect of application of rice straw and cellulose on methane emission and biological nitrogen fixation in a subtropical paddy field. I. Methane emission, soil-ARA, and rice plant growth. Soil Sci. Plant Nutr. 42: 701-711.

44) Rajagopal, B.S., N. Belay and L. Daniels. 1988. Isolation and characterization of methanogenic bacteria from rice paddies. FEMS Microbiol. Ecol. 53: 153-158.

45) Schütz, H., A. Holzapfel-Pschorn, R. Conrad, H. Rennenberg and W. Seiler. 1989. A 3-year continuous record on the influence of daytime, season, and fertilizer treatment on methane emission rates from an Italian rice paddy. J. Geophys. Res. 94: 1640516416.

46) Schütz, H., W. Seiler and R. Conrad. 1989. Processes involved in formation and emission of methane in rice paddies. Biogeochem. 7: 33-35.

47) Shen, C.F., C.B. Miguez, D. Bourque, D. Groleau and S.R. Guiot. 1996. Methanotroph and methanogen coupling in granular biofilm under $\mathrm{O}_{2}$-limited conditions. Biotechnology Letters 18: 495500.

48) Shin, Y.-K. and S.-H. Yun. 2000. Varietal differences in methane emission from Korean rice cultivars. Nutr. Cycling Agroecosys. 58: $315-319$.
49) Takeda, K. 1988. Characteristics of a nitrogen-fixing methanotroph, Methylocystis T-1. Antonie van Leeuwenhoek 54: 521-534.

50) Takeda, K. 1998. Ecology and characteristics of methanogens and methanotrophs in paddy soil. Microb. Environ. 13: 39-44 (in Japanese with English summary).

51) Takeda, K., S. Motomatsu, Y. Hachiya, S. Fukuoka and Y. Takahara. 1974. Characterization and culture conditions for a methane-oxidizing bacterium. J. Ferment. Technol. 52: 793-798 (in Japanese with English summary).

52) Takeda, K., S. Suzuki, K. Neko, Y. Tomiyama, T. Fujita, N. Matsuyama and I. Watanabe. 1998. Enumeration and characteristics of methanotrophs in paddy soils and rice roots. Jpn. J. Soil Sci. Plant Nutr. 69: 570-575 (in Japanese with English summary).

53) Takeda, K. and K. Tanaka. 1980. Ultrastructure of intracytoplasmic membranes of Methanomonas margaritae cells grown under different conditions. Antonie van Leeuwenhoek 46: 15-25.

54) Tsien, H.C., B.J. Bratina, K. Tsuji and R.S. Hanson. 1990. Use of oligodeoxynucleotide signature probes for identification of physiological groups of methylotrophic bacteria. Appl. Environ. Microbiol. 56: 2858-2865.

55) Van Bodegom, P., F. Stams, L. Mollema, S. Boeke and P. Leffelaar. 2001. Methane oxidation and the competition for oxygen in the rice rhizosphere. Appl. Environ. Microbiol. 67: 3586-3597.

56) Wang, B. and K. Adachi. 2000. Differences among rice cultivars in root exudation, methane oxidation, and populations of methanogenic and methanotrophic bacteria in relation to methane emission. Nutr. Cycling Agroecosys. 58: 349-356.

57) Wang, B., K. Adachi and K. Nakamura. 1999. Rice cultivar difference can significantly influence $\mathrm{CH}_{4}$ emission rate in rice field. World Resource Review 11: 409-419.

58) Wang, B., H.U. Neue and H.P. Samonte. 1997. Effect of cultivar difference ('IR72', 'IR65598' and 'Dular') on methane emission. Agric. Ecosys. Environ. 62: 31-40.

59) Wang, B., Y. Xu, Z. Wang, Z. Li, Y. Guo, K. Shao and Z. Chen. 1999. Methane emissions from ricefields as affected by organic amendment, water regime, crop establishment, and rice cultivar. Environ. Monitor. Assess. 57: 213-228.

60) Wassmann, R., R.S. Lantin, H.U. Neue, L.V. Buendia, T.M. Corton and Y. Lu. 2000. Charactirization of methane emissions form rice fields in Asia. III. Mitigation options and future research needs. Nutr. Cycling Agroecosys. 58: 23-36.

61) Wassmann, R., H. Papen and H. Rennenberg. 1993. Methane emission from rice paddies and possible mitigation strategies. Chemosphere 26: 201-217.

62) Watanabe, A., M. Kajiwara, T. Tashiro and M. Kimura. 1995. Influence of rice cultivar on methane emission from rice paddy fields. Plant Soil 176: 51-56.

63) Watanabe, I., T. Hashimoto and A. Shimoyama. 1997. Methaneoxidizing activities and methanotrophic populations associated with wetland rice plants. Biol. Fertil. Soils 24: 261-265.

64) Whittenbury, R., K.C. Phillips and J.F. Wilkinson. 1970. Enrichment, isolation and some properties of methane-utilizing bacteria. J. Gen. Microbiol. 61: 205-218.

65) Yagi, K. and K. Minami. 1990. Effect of organic matter application on methane emission from some Japanese paddy fields. Soil Sci. Plant Nutr. 36: 599-610.

66) Yagi, K., H. Tsuruta and K. Minami. 1997. Possible options for mitigating methane emission from rice cultivation. Nutr. Cycling Agroecosys. 49: 213-220.

67) Yao, H., K. Yagi and I. Nouchi. 2000. Importance of physical plant properties on methane transport through several rice cultivars. Plant Soil 222: 83-93. 